\title{
Mechanical properties of sulphate reduction bacteria on the durability of concrete in chloride condition
}

\author{
Teddy Tambunan ${ }^{1, *}$, Mohd. Irwan Juki ${ }^{1}$, and Norzila Othman ${ }^{2}$ \\ ${ }^{1}$ Jamilus Research Centre for Sustainable Construction (JRC), Faculty of Civil and Environmental Engineering, Universiti Tun \\ Hussein Onn, Malaysia. \\ ${ }^{2}$ Micro Pollutant Research Centre (MPRC), Faculty of Civil and Environmental Engineering, Universiti Tun Hussein Onn, Malaysia
}

\begin{abstract}
In construction, concrete durability is an important material globally used in engineering, material of which can be applied in the fields of specialized marine construction. The ingress of chloride into concrete causes deterioration in the concrete due to the reinforcement corrosion. Adding bacteria into concrete can improve material properties and increase durability with mechanism resist chloride ingressed in the concrete. Ingress of Chloride into the concrete of bacteria is particularly suited for applications of chloride ion penetration in concrete. The objective of the research is to determine the effect of adding bacteria into the concrete properties. The bacteria used in this research is locally isolated and enriched to the suite with the concrete environment. The type of the bacteria used is identified as Sulphate Reduction Bacteria (SRB). The SRB added into the concrete mix with concentrations of $3 \%, 5 \%$ and $7 \%$. Whereas, concentration of bacteria water of cement is 0.5 . The mechanical properties test conducted with 28 th, 56th, 90th, 180th and 360th day of curing period. The test was using cyclic wetting and drying to study the exposure to chloride condition, such as compressive strength, tensile strength and flexural test. Cubes in the size of $150 \mathrm{~mm} \times 150 \mathrm{~mm} \times 150 \mathrm{~mm}$ were prepared for compressive strength test and cylinder 150 $\mathrm{mm} \times 300 \mathrm{~mm}$ were prepared for the tensile strength test. The flexural strength test was on the prism in the size of $100 \mathrm{~mm} \times 100 \mathrm{~mm} \times 500 \mathrm{~mm}$. The result of compressive strength test shows, that gave significant strength of $66.3 \mathrm{MPa}$ on the 360th day. The tensile strength and flexural strength have a similar trend as compressive strength results, where both results were optimum . The tensile strength test shows that 4.52 $\mathrm{MPa}$ tends to control $3.96 \mathrm{MPa}$. The result of flexural strength test was 8.23 MPa for compared to control of $5.99 \mathrm{MPa}$. The overall results of the bacteria indicate promising outcome and further study on chloride condition capability is encouraging.
\end{abstract}

\section{Introduction}

In the archipelago of a long coastal zone, sea water concrete structures constantly exposed to extreme conditions, such as sea water. This condition affects the durability of the concrete structure due to environmentrelated factors such chemicals, sulfates, and chlorides contained in the sea water. Among the threatening factors such as freezing and thawing, abrasion, and corrosion of steel, the chemical attack may significantly deteriorate the concrete [1]. Chemical attack can be classified as an acidic attack, alkali attack, carbonation, chloride attack, leaching and sulphate attack. The threat to be discussed and investigated in this study is chloride attack. Chloride is considered as an extreme attack in causing the corrosion of steel in concretes. Chloride ingress on concrete is one of the most important aspects for considering the durability of concretes. The primary cause of corrosion of reinforcement is particularly
Chloride attack. Statistics have indicated that over 40 per cent of failure of structures is due to corrosion of reinforcement [2]. In a concrete with high alkalinity, a protective oxide film is present on the surface of steel reinforcement. The protective passive layer can be lost due to carbonation. This protective layer can also be lost due to the existence of chloride in the presence of water and oxygen. In reality, the impact of chloride in inducing corrosion of reinforcement is more serious than any other reasons [3].

Furthermore, corrosion of reinforcing steel due to chloride ingress is one of the most common environmental attacks that lead to the deterioration of concrete structures. Information about mechanisms of deterioration to corrosion-related damages to bridge deck overlays, parking garages, marine structures, and manufacturing plants are the most studied by the researcher [4]. Deterioration of concrete causes more effect to the environment of the system in conjunction with the structural requirement to describe the cause of

\footnotetext{
* Corresponding author: teddy bhagas@yahoo.com
} 
such deterioration [5]. Environment factors consisting of seasonal variations freeze thaw cycling, relative humidity, and chemicals in the ground and ground water are the main degradation agents.

A typical durability-related phenomenon in many concrete constructions is crack formation. While larger cracks hamper structural integrity, smaller submillimetre sized cracks may also resulting durability problems, as particularly connected cracks increases matrix permeability [6]. Durable concrete with biological approach is known as bio-concrete, in which microorganism is one of the most important in the deterioration of porous materials and sealing concrete cracks [7]. However, bacteria are unable to tolerate all environmental conditions because there are some factors restricting the growth of bacteria, such as temperature, type of growth medium, extreme $\mathrm{pH}$ value and anaerobic conditions. Bacteria successfully isolated to survive in the alkaline environment with anaerobic conditions, and further labelled as sulphate reduction bacteria [8].

Theoretically, sulphate reduction bacteria (SRB) require dissolved oxygen to induce the corrosion cycle, as the bacteria were not able to tolerate extreme $\mathrm{pH}$ value. Under an acidic condition, these bacteria cells hydrolyze or the enzyme inactivate. If the surrounding environment of the SRB is in an alkaline condition, the enzymes work very well. The $\mathrm{pH}$ value plays an important role in microbial life that will affect the dissociation and solubility of many molecules that indirectly affect the microorganism research methodologies, especially those incorporating the biological effect on concrete. The study of isolating SRB from acid mine water indicates that the optimal $\mathrm{pH}$ for growth condition is 9.35 [9]. The bacteria incorporation in concrete reduces mass variation, volume variation (higher age) and water absorption [10]. Therefore, the objective of this study is to investigate the effect of SRB concentrations as influenced by water cement ratio (W/C) on the chloride attack during curing period of up to 360 days on the mechanical properties test.

\section{Experimental program}

\subsection{Isolation of sulphate reduction bacteria}

SRB used in this study collected from domestic acidic water located in Sungai Pelepah Kota Tinggi, Johor, Malaysia. The following isolation and preparation samples are Alshalif et al. [8]. SRB was enriched under a special environment to tolerate high alkalinity and anaerobic conditions to ensure sustainability in the concrete. In this study, sodium chloride $(\mathrm{NaCl})$ was added to simulate the chloride environment during an isolated SRB culture.

Therefore, as required under BS EN 13396: 2014, it increases the durability of concrete as it will prevent water from seeping in to the concrete, which causing the carbonation of the steel and ultimately threatening the entire structure of the concrete to become not durable. In this study, the reduction of water permeation also minimizes the penetration of $3 \%$ sodium chloride which is soluble in curing water. Chloride is an important cause in creating corrosion to any steel material in a concrete structure. Thereby, it reduces the durability of concretes [11]. The composition of the media in the culture SRB process is prepared, as follows:

a) Control $=25 \mathrm{ml}$ (nutrient broth) $+10 \mathrm{ml}(3 \%$ $\mathrm{NaCl})=35 \mathrm{ml}$

b) $\mathrm{SRB}$ sample $=25 \mathrm{ml}$ (nutrient broth) $+10 \mathrm{ml}$ ( $3 \% \mathrm{NaCl})+1$ bead of $\mathrm{SRB}=35 \mathrm{ml}$

\subsection{Materials}

The bacteria growth curve was plotted based on enriched bacteria to suit the concrete environment of the bacteria until the bacteria reaches optimum growth condition. Bio-concrete mixture was designed to meet the amount as referred under G35 according to DOE [12]. The methods for mixing and sampling fresh concretes are conducted in the laboratory. According to the standards, half of the total amount of sand is first to be poured into the mixer drum, after which coarse aggregate is added. Once homogeneity has been achieved, the other half of the sand is to be added, followed by the cement. The water is slowly added then the whole mixture is left to mix until reach the form of homogenous. After the concrete is homogenous, the bacteria are added into the $\operatorname{mix}$ (figure 1).

Workability of the concrete mix was tested using slump test. Concrete mix proportion was using a different percentage of SRB concentration and percentage of the bacteria used was calculated as a partial replacement of water. $0.5 \mathrm{w} / \mathrm{c}$ was applied to achieve the target strength as tabulated in Table 1. All procedure in preparation of bio-concrete was based on BS 1881-125:2013 [12].

Table 1. Mix proportion of bio-concrete with different percentages of SRB prepared for fabrication

\begin{tabular}{|l|c|c|c|c|c|}
\hline Specimen & $\begin{array}{c}\text { Cement } \\
(\mathrm{kg})\end{array}$ & $\begin{array}{l}\text { Fine } \\
\text { agg. } \\
(\mathrm{kg})\end{array}$ & $\begin{array}{c}\text { Coarse } \\
\text { agg. } \\
(\mathrm{kg})\end{array}$ & $\begin{array}{c}\text { Water } \\
(\mathrm{kg})\end{array}$ & $\begin{array}{c}\text { Bacteri } \\
\mathrm{a} \\
(\mathrm{kg})\end{array}$ \\
\hline Ratio (DOE) & 410 & 673 & 1098 & 210 & - \\
\hline Control & 65.1 & 149 & 91.3 & 29.04 & - \\
\hline$S R B 3 \%$ & 65.1 & 149 & 91.3 & 28.01 & 1.03 \\
\hline$S R B 5 \%$ & 65.1 & 149 & 91.3 & 27.33 & 1.71 \\
\hline$S R B 7 \%$ & 65.1 & 149 & 91.3 & 26.65 & 2.39 \\
\hline
\end{tabular}

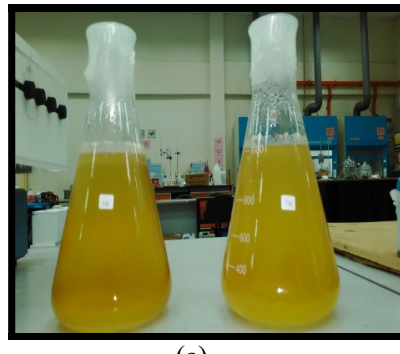

(a)

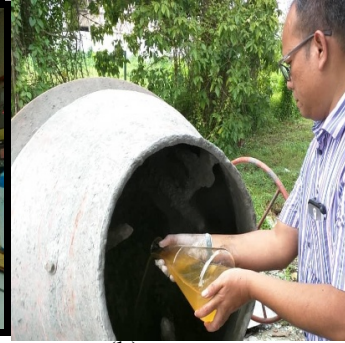

(b)
Fig. 1. (a) Bacteria used in this research, (b) Pouring concrete mixing with bacteria 


\subsection{Test procedure}

The performed mechanical properties tests are compressive strength, tensile strength and flexural strength test. All tests for third compressive strength, tensile strength and flexural test were conducted in triplicate samples. The cubes molds of $150 \mathrm{~mm} \mathrm{x}$ $150 \mathrm{~mm} \times 150 \mathrm{~mm}$ were prepared both with and without (SRB). In order to simulate chloride condition, concrete specimens were cured in $3 \% \mathrm{NaCl}$ for $28,56,90,180$ and 360 days. Compressive strength test was performed according to BS EN 12390-3:2009 [13] using universal testing machine (UTM). Tensile strength test was conducted using cylinder in the size of $150 \mathrm{~mm} \mathrm{x}$ $300 \mathrm{~mm}$ diameter. The test was conducted in accordance with the BS EN 12390-6:2009 [14].

Flexural strength test using prism $100 \mathrm{~mm}$ x100 mm x $150 \mathrm{~mm}$ according to BS EN 12390-5:2009 in order to determine the increase in resistance towards the flexural strength in concrete specimens [15].

\subsection{Wetting and drying cycles on Laboratory}

Mechanism of cyclic wetting and drying cyclic for deeper penetration cause at the rate of 20 times by continuous immersion [16]. The concrete were cured for minimum of 28 days to achieve strength, after 28 days of curing the specimen under water to transfer sodium chloride solution $(\mathrm{NaCl})$ with 15 hours of wetting and 9 hours of drying [17] and this method proven to be successful to use.

\section{Result and discussion}

\subsection{Compressive strength test}

Results on the compressive strength of bacteria concrete specimens were prepared with different SRB percentage (i.e. $3 \%, 5 \%$ and $7 \%$ ) as influenced by $\mathrm{W} / \mathrm{C}$ ratio of 0.5 are presented in table 2. All specimens had been tested after achieving maturity of concrete on the day 28, 56, 90, 180 and 360. As shown in Figure 2, specimens containing $0.5 \mathrm{~W} / \mathrm{C}$ ratio with bacterial (SRB) indicate a considerable increase in the compressive strength ( $\mathrm{MPa})$ as compared to a control specimen.
Table 2. Compression test of concrete with different SRB percentage

\begin{tabular}{|c|c|c|c|c|}
\hline \multirow{2}{*}{$\begin{array}{c}\text { Curing } \\
\text { time } \\
\text { (days) }\end{array}$} & \multicolumn{4}{|c|}{ Compression strength, MPa } \\
\cline { 2 - 5 } & Control & $3 \%$ SRB & $5 \%$ SRB & $7 \%$ SRB \\
\hline 28 & 42.23 & 48.8 & 46.60 & 47.20 \\
\hline 56 & 41.03 & 49.5 & 49.53 & 47.57 \\
\hline 90 & 43.30 & 47.00 & 53.87 & 48.50 \\
\hline 180 & 53.20 & 63.90 & 58.57 & 58.70 \\
\hline 360 & 41.23 & 46.97 & 66.33 & 53.37 \\
\hline
\end{tabular}

On the day 180, the highest compressive strength occurred at $3 \%$ of SRB (63.9 MPa) followed by $5 \%$ of SRB (58.6 MPa) and 7\% of SRB (58.7 MPa). However, this value is still higher than the minimum requirement of compressive strength of concrete grade $35(35 \mathrm{MPa})$, as simulated in this study. Meanwhile, $5 \%$ and $7 \%$ of SRB were increasing gradually in compressive strength on the day 180 of curing time reaching $63.9 \mathrm{MPa}$, respectively.

If compared to a control specimen, the compressive strength of bacteria concrete in $0.5 \mathrm{~W} / \mathrm{C}$ ratio on the day 180 of curing time has increased up to $20.11 \%, 10.08 \%$ and $10.34 \%$ for $3 \%, 5 \%$ and $7 \%$ of SRB, respectively. It was indicated that $0.5 \mathrm{~W} / \mathrm{C}$ ratio in concrete mixture highly influences the strength after 180 days of curing in $5 \%$ and $7 \%$ of SRB (figure 2). Most of the specimens with different SRB percentage including a control specimen indicates no major changes in the compressive strength. Figure 2 shown, on the day 360 of curing time, there was a clear trend of increase in compressive strength for $5 \%$ of SRB specimens increased up to $60.87 \%$ compare the control specimen by applying 0.5 $\mathrm{W} / \mathrm{C}$ ratio.

Theoritically, pores in bacteria concrete are partially filled up by material growth with the addition of bacteria in which leads to increased density of the concrete strength [18]. Applied Bacillus subtilis for repairing crack of concrete indicate $30 \%$ increase in the compressive strength of bacteria concrete specimens compared to control specimen, this situation occurred because of the bacteria precipitation of calcium carbonate on the surface and in the pores of the specimens [19].

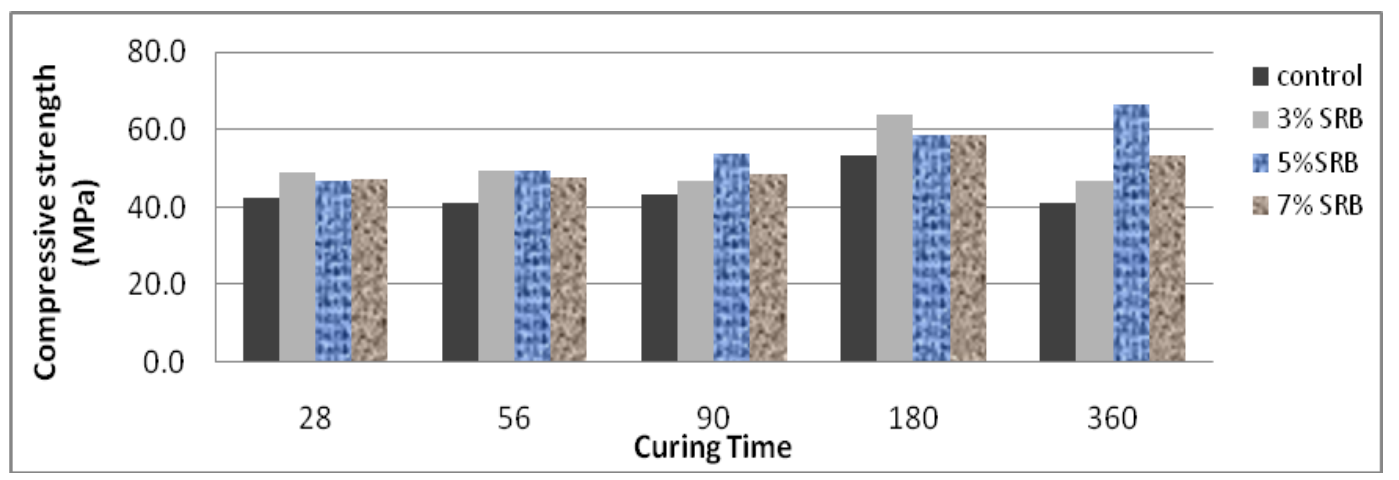

Fig. 2. Compressive strength with different percentage of SRB as influenced by $0.5 \mathrm{~W} / \mathrm{C}$ ratio 


\subsection{Tensile strength}

Tensile strength test was conducted to determine the influence of bacteria on tensile strength. The average result of the tensile strength is as shown in Table 3 and Figure 3. The tensile strength results increase the addition of SRB in concrete specimens. The highest increment of tensile strength is with 5\% SRB. On the 360 day the tensile strength increased by $14.12 \%$ with concrete specimens containing 5\% SRB compared to control. Then the addition of $3 \%$ and $7 \%$ SRB in concrete specimens increased tensile strength by $13.54 \%$ and $9.92 \%$ on the 360 days. The increment of tensile strength obtained with $3 \%, 5 \%$ and $7 \%$ SRB compared to concrete specimens control are $14.12 \%$, $48.34 \%$ and $13.63 \%$ respectively on the 180 days curing time. The indicate increment of tensile strength of bioconcrete indicates significant increases on 180 days and 360 days. Previous researchers has published similar results in which the addition of bacterial precipitation increases the strength of concrete [20], [21].

Table 3. Tensile test of concrete with different SRB percentage

\begin{tabular}{|c|c|c|c|c|}
\hline \multirow{2}{*}{$\begin{array}{c}\text { Curing } \\
\text { time } \\
\text { (days) }\end{array}$} & \multicolumn{4}{|c|}{ Tensile strength, MPa } \\
\cline { 2 - 5 } & Control & $\begin{array}{c}3 \% \\
\text { SRB }\end{array}$ & $\begin{array}{c}5 \% \\
\text { SRB }\end{array}$ & $\begin{array}{c}7 \% \\
\text { SRB }\end{array}$ \\
\hline 28 & 3.16 & 3.18 & 3.41 & 3.19 \\
\hline 56 & 3.29 & 3.54 & 3.72 & 3.56 \\
\hline 90 & 3.12 & 3.81 & 3.23 & 3.25 \\
\hline 180 & 3.13 & 4.03 & 4.64 & 3.56 \\
\hline 360 & 3.96 & 4.50 & 4.52 & 4.36 \\
\hline
\end{tabular}

\subsection{Flexural strength}

The results of the test are presented in table 4 and figure 4. The addition SRB on concrete specimen G35 has increased the flexural strength of concrete. The addition $5 \%$ SRB in concrete on 360 days has increased the flexural strength by $37.44 \%$ ( $8.23 \mathrm{MPa}$ ) compared to the controlled one. This was followed by $15.95 \%$ increment by $7 \%$ SRB and $10.75 \%$ increment by $3 \%$ SRB of specimens compared to the controlled one. The addition of $3 \%, 5 \%$ and $7 \%$ SRB has increased the flexural strength by $26.53 \%, 52.30 \%$ and $28.45 \%$ respectively compared to control the controlled one on 90 days curing time. The highest increment of flexural strength was with 5\% SRB (8.99 MPa), respectively.

Table 4. Flexure Strength of concrete with different SRB percentage

\begin{tabular}{|c|c|c|c|c|}
\hline \multirow{2}{*}{$\begin{array}{c}\text { Curing } \\
\text { time } \\
\text { (days) }\end{array}$} & \multicolumn{4}{|c|}{ Tensile strength, MPa } \\
\cline { 2 - 5 } & Control & $\begin{array}{c}3 \% \\
\text { SRB }\end{array}$ & $\begin{array}{c}5 \% \\
\text { SRB }\end{array}$ & $\begin{array}{c}7 \% \\
\text { SRB }\end{array}$ \\
\hline 28 & 4.64 & 5.58 & 5.66 & 4.77 \\
\hline 56 & 4.73 & 6.39 & 6.39 & 5.13 \\
\hline 90 & 5.91 & 7.47 & 8.99 & 7.59 \\
\hline 180 & 4.08 & 5.04 & 6.44 & 6.04 \\
\hline 360 & 5.99 & 6.63 & 8.23 & 6.94 \\
\hline
\end{tabular}

The improvements of flexure strength in bio-Concrete as in this study is also supported by the previous study [22], [23]. The mechanism of this activity can be further explained to be affected by calcium carbonate precipitation in the bio-concrete specimen. Therefore, the addition of bacteria (SRB) into bio-concrete has improved the concrete flexural strength by producing calcium carbonate, which reduces the pores at a faster rate of concrete correlates well with the previous study which states that the addition of bacteria has a profound impact to the flexural strength of prism by deposition of calcium lactate by bacteria [24].

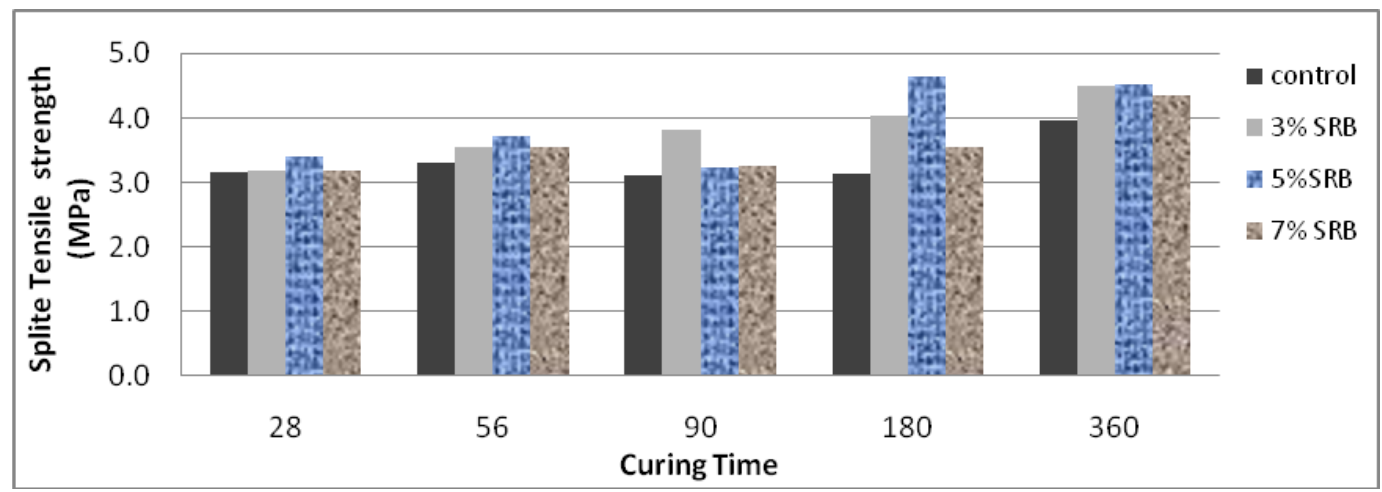

Fig. 3. Tensile strength of different concentrations of SRB as influenced by $0.5 \mathrm{~W} / \mathrm{C}$ ratio

\footnotetext{
* Corresponding author: teddy bhagas@yahoo.com
} 


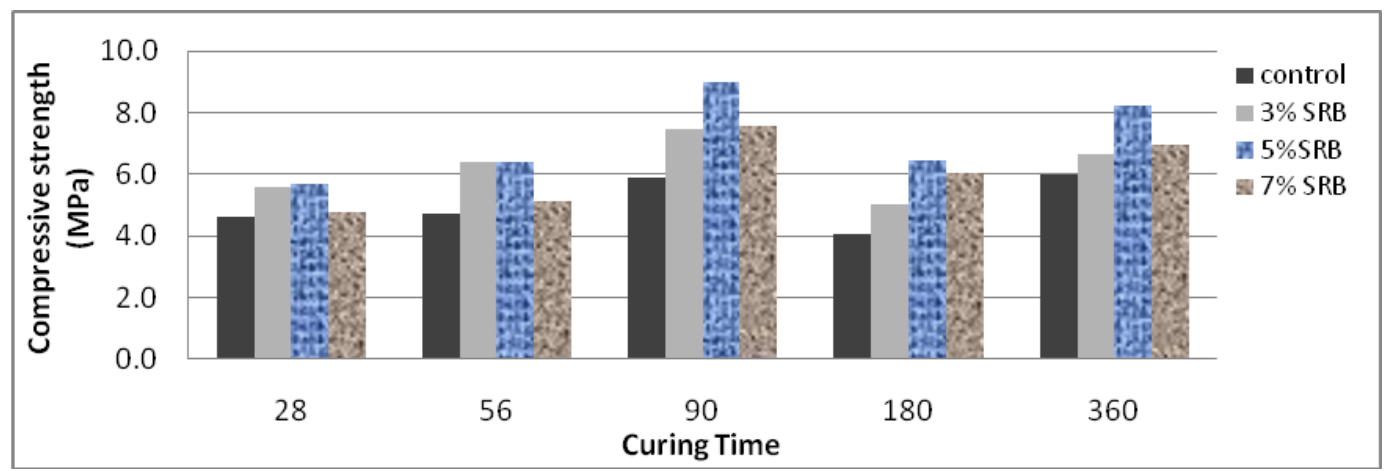

Fig. 4. Flexure strength of different concentrations of SRB as influenced by $0.5 \mathrm{~W} / \mathrm{C}$ ratio

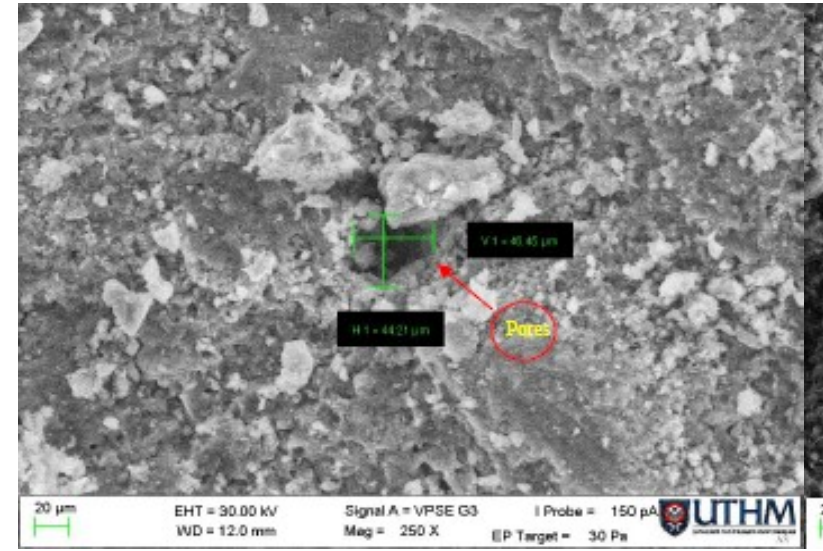

(a)

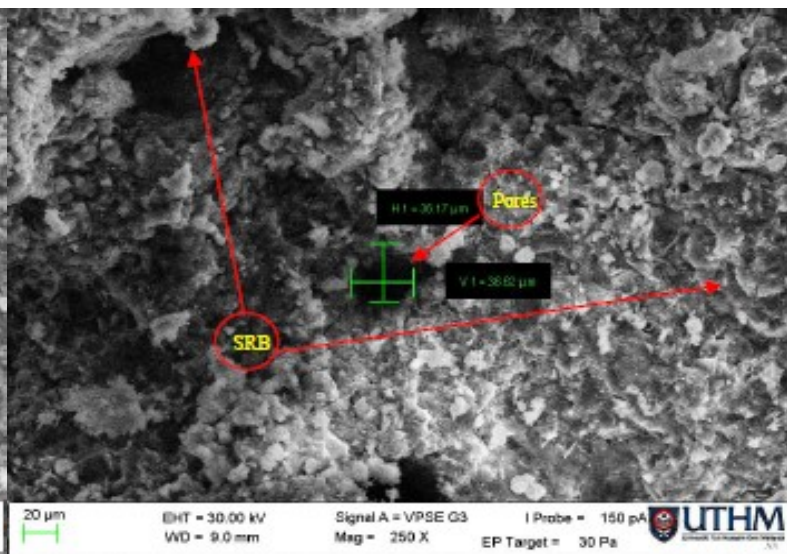

(b)

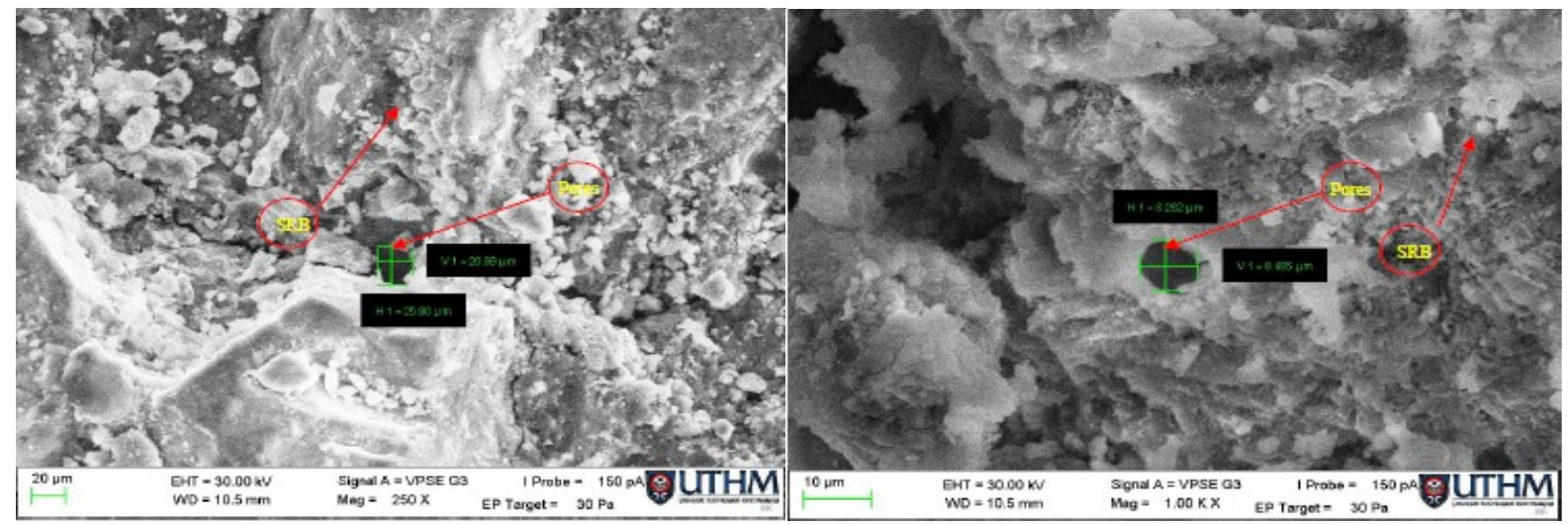

(c)

(d)

Fig. 5. Microstructure analysis of concrete : (a) Control concrete, (b) Concrete with $3 \% S R B$, (c) Concrete with $5 \% S R B$, and (d) Concrete with $7 \% S R B$

\subsection{Microstructure analysis results}

The microstructure analysis is used to identify difference in surface structure of concrete with and without bacteria. Figure 5 shows the results for microstructure analysis conducted on control concrete and concrete with SRB. Control image generally showed rough and uneven surface. This porous surface from the control samples lead to the increase of absorption capacity of concrete and hence decrease the durability. In the concrete with SRB part of the porous surface has been filled, thus causing reduction in the pore size. The ability for bacteria to deposit calcium carbonate in pores within the concrete without any encapsulation during concrete mixing shows that the bacteria is durable enough to withstand concrete mixing process.

\section{Conclusion}

This study was designed to investigate the effect of sulphate reduction bacteria (SRB) on compressive strength, tensile strength and flexure strength as 
influenced by water cement ratio $(\mathrm{w} / \mathrm{c})$ on bio-concrete structure on chloride condition. The results of this study indicate that the ratio of water that frequently used in the construction application is $0.5 \mathrm{w} / \mathrm{c}$, while the most precise concentration of SRB is $5 \%$. These findings were obtained according to the highest mechanical properties observed during the curing period. More broadly, research is needed to determine rapid chloride penetration test (RCPT) in bio-concrete combined with further investigation under chloride conditions, such as chloride attack. Thus, this innovation could be applied as the latest alternative in construction especially for structures in coastal areas.

This study has been granted by the Ministry of Higher Education (MOHE) under Fundamental Research Grant Scheme (FRGS Vot. 1577) and supported by Universiti Tun Hussein Onn Malaysia (GPPS Vot. U445).

\section{References}

1. V. Zivica, and A. Bajza, Acidic attack of cement based materials-a review. Part 1. Principle of acid attack. Construction and Building Materials, 15(8): 331-340 (2001)

2. S.K. Verma, S.S. Bhadauria, and S. Akhtar, Evaluating effect of chloride attack and concrete cover on the probability of corrosion. Frontiers of Structural and Civil Engineering, 7(4): 379-390 (2013)

3. M.S. Darmawan, Pitting corrosion model for reinforced concrete structures in a chloride environment. Magazine of Concrete Research, 62(2): 91-101 (2010)

4. H.A. Neville, E. Oh, L.B. Spanierman, M.J. Heppner, and M. Clark, General and culturally specific factors influencing black and white rape survivors' self-esteem. Psychology of Women Quarterly, 28(1): 83-94 (2004)

5. C. Suwito, and Y. Xi, The effect of chloride-induced steel corrosion on service life of reinforced concrete structures. Structure and Infrastructure Engineering, 4(3): 177-192 (2008)

6. J.L. Jonker, J. Von Byern, P. Flammang, W. Klepal, and A.M. Power, Unusual adhesive production system in the barnacle Lepas anatifera: An ultrastructural and histochemical investigation. Journal of Morphology, 273(12): 1377-1391 (2012)

7. L.H. Anneza, J.M. Irwan, N. Othman, N. and A.F. Alshalif, Identification of Bacteria and the Effect on Compressive Strength of Concrete. MATEC Web of Conferences, 47:1008 (2016)

8. A.F. Alshalif, J.M. Irwan, N. Othman, and L.H. Anneza, Isolation of sulphate reduction bacteria (SRB) to improve compress strength and water penetration of bio-concrete. MATEC Web of Conferences, 47:1-6 (2016)

9. J.M. Irwan, L.H. Anneza, N. Othman, and A.F. Alshalif, Compressive strength and water penetration of Concrete with Enterococcus Faecalis and calcium lactate. Key Engineering Materials,
705: 345-349 (2016)

10. A. Gandhimathi, and D. Suji, Studies on the Development of Eco-friendly Self-healing ConcreteA Green Building Concept. Nature Environment and Pollution Technology, 14(3): 639-644 (2015)

11. F. Nosouhian, D. Mostofinejad, and $\mathrm{H}$. Hasheminejad, Concrete Durability Improvement in a Sulfate Environment Using Bacteria, in The Journal of Materials in Civil Engineering, 28(1) (2015)

12. BSI 1881. Testing Concrete: Part 125: 2013. Methods for mixing and sampling fresh concrete in the laboratory, London.

13. BSI EN 12390. Part 3: 2009, Compressive strength of test specimens, London.

14. British Standard Institution Testing hardened concrete part 6: Tensile splitting strength of test specimens. BS EN 12390-6:2009.

15. British Standard Institution. Testing hardened concrete part 5: Flexural strength of test specimens. BS EN 12390-5:2009

16. W.J. Mc.Carter, D. Watson, Wetting and drying of cover-zone concrete, Proceedings of the Institution of Civil Engineers, Structures and Buildings, 122(2), 227-236 (1997)

17. S.U. Al-Dulaijan, M. Maslehuddin, M.M. AlZahrani, A.M. Sharif, M. Shameem, and M. Ibrahim, Sulfate resistance of plain and blended cements exposed to varying concentrations of sodium sulfate, Cement and Concrete Composites, 25(4),429-437 (2003)

18. N.G. Babu, and S. Siddiraju, An Experimental Study on Strength and Fracture Properties of Self Healing Concrete. International Journal of Civil Engineering and Technology, 7(3): 398-406 (2016)

19. H. Kalhori, and R. Bagherpour, Application of carbonate precipitating bacteria for improving properties and repairing cracks of shotcrete, Construction and Building Materials, 148: 249-260 (2017)

20. F.U.A. Shaikh and S.W.M. Supit, Mechanical and durability properties of high volume fly ash (HVFA) concrete containing calcium carbonate $\left(\mathrm{CaCO}_{3}\right)$ nanoparticles, Construction and building materials, 70(2014),309-321

21. C.C. Gavimath, B.M. Mali, V.R. Hooli, J.D. Mallpur, A.B. Patil, Potential application of bacteria to improve the strength of cement concrete, International Journal of Advanced Biotechnology and Research, ISSN 0976-2612, Vol.3, Issue 1, pg. 541-544 (2012)

22. J.M. Irwan, L.H. Anneza, N. Othman, A.F. Alshalif, M.M. Zamer, and T. Teddy, Mechanical Properties of Concrete with Enterococcus Faecalis and Calcium Lactate. Procedia Engineering, 171, 592-597 (2017)

23. J.M. Irwan, L.H. Anneza, N. Othman, and A.F. Alshalif, Compressive strength and water penetration of Concrete with Enterococcus Faecalis and calcium lactate. Key Engineering Materials, 705, 345-349 (2016) 
24. S. Majumdar, M. Sarkar, T. Chowdhury, B.

2(04),218 (2012) Chattopadhyay, and S. Mandal, Use of bacterial protein powder in commercial fly ash pozzolana cements for high performance construction materials, Open Journal of Civil Engineering, 